\title{
Calcium Signaling of Dioleoyl Phosphatidic Acid via Endogenous LPA Receptors: A Study Using HCT116 and HT29 Human Colon Cancer Cell Lines
}

\author{
Young-Ja Chang, Hyo-Lim Kım, Santosh J. SACKet, Kyeok Kim, Mijin Han, \\ Ji-Yeong Jo, and Dong-Soon IM* \\ Laboratory of Pharmacology, College of Pharmacy (BK21 Project) and \\ Research Institute for Drug Development, Pusan National University, Busan 609-735, Republic of Korea
}

(Received 6 July 2007; Accepted 2 August 2007)

\begin{abstract}
In the present study, we have tested the effect of dioleoyl phosphatidic acid (PA) on intracellular $\mathrm{Ca}^{2+}$ concentration $\left(\left[\mathrm{Ca}^{2+}\right]_{\mathrm{j}}\right)$ in two human colon cancer cell lines (HCT116 and HT29). PA and lysophosphatidic acid (LPA), a bioactive lysolipid, increased $\left[\mathrm{Ca}^{2+}\right]_{\mathrm{i}}$ in both HCT116 and HT29 cell lines. Increases of $\left[\mathrm{Ca}^{2+}\right]_{\mathrm{i}}$ by PA and LPA were more robust in HCT116 cells than in HT29 cells. A specific inhibitor of phospholipase C (U73122), however, was not inhibitory to the cell responses. Pertussis toxin, a specific inhibitor of $\mathrm{G}_{\mathrm{i} / \mathrm{o}}$ type $\mathrm{G}$ proteins, however, had an inhibitory effect on the responses except for an LPA-induced one in HT29 cells. Ruthenium red, an inhibitor of the ryanodine receptor, was not inhibitory on the responses, however, 2-APB, a specific inhibitor of inositol 1,4,5-trisphosphate receptor, completely inhibited both lipid-induced $\mathrm{Ca}^{2+}$ increases in both cell types. Furthermore, by using Ki16425 and VPC 32183 , two structurally dissimilar specific antagonists for $\mathrm{LPA}_{1} / \mathrm{LPA}_{3}$ receptors, an involvement of endogenous LPA receptors in the $\mathrm{Ca}^{2+}$ responses was observed. Ki16425 completely inhibited the responses but the susceptibility to VPC32183 was different to PA and LPA in the two cell types. Expression levels of five LPA receptors in the HCT116 and HT29 cells were also assessed. Our data support the notion that PA could increase $\left[\mathrm{Ca}^{2+}\right]_{\mathrm{i}}$ in human colon cancer cells, probably via endogenous LPA receptors, $\mathrm{G}$ proteins and $\mathrm{IP}_{3}$ receptors, thereby suggesting a role of $\mathrm{PA}$ as an intercellular lipid mediator.
\end{abstract}

Keywords $\square$ phosphatidic acid; lysophosphatidic acid; G-protein-coupled receptor; calcium; LPA 1 , LPA

\section{INTRODUCTION}

Dioleoyl phosphatidic acid (PA) is a minor fraction of the intracellular phospholipid pool. However, PA has been proposed as a second messenger for many stimuli and its action on intracellular signaling molecules such as mTOR has been intensively studied (Fang et al., 2001; Hornberger et al., 2006; Stace and Ktistakis, 2006). On the other hand, exogenous PA has been shown to induce calcium influx in a number of biological tissues including isolated platelets (Gerrard et al., 1978; Ikeda et al., 1979; Imai et al., 1982), the parotid gland (McGhee and Shoback, 1990; Weiss et al., 1982), liver cells (Barritt et al., 1981; Osugi et al., 1984), nerve terminals (Harris et al., 1981), epithelium (Lee et al., 1989), osteoblasts (Kawase and Suzuki, 1988, 1990), and cardiac myocytes (Kurz et al., 1993) and shown to exert potent mitogenic effects (Bashir et

*Corresponding author

Tel: $+82-51-510-2817$, Fax: $+82-51-513-6754$

E-mail: imds@pusan.ac.kr al., 1992; Knauss et al., 1990; Krabak and Hui, 1991; Pearce et al., 1994; Siegmann, 1987; Wood et al., 1993). Nevertheless, the findings that lysophosphatidic acid (LPA) is a potent mitogenic lipid (van Corven et al., 1989) and that commercial preparations of PA were contaminated with LPA has shifted importance from PA to LPA (Jalink et al., 1990). Contrary to the above citations, growth factors induce cellular proliferation through PA dependent activation of mitogen-activated protein

Abbreviations used are: PA, dioleoyl phosphatidic acid; LPA, lysophosphatidic acid; VPC32183, (S)-Phosphoric acid mono\{2-octadec-9-enoylamino-3-[4-(pyridine-2-ylmethoxy)-phenyl]propyl\} ester; Ki16425, 3-(4-[4-([1-(2-Chlorophenyl)ethoxy] carbonylamino)-3-methyl-5-isoxazolyl]benzylthio) propanoic acid; PTX pertussis toxin; GPCR, G-protein-coupled receptor; $\mathrm{LPA}_{1}$, lysophosphatidic acid receptor type 1 (EDG2); $\mathrm{LPA}_{2}$, lysophosphatidic acid receptor type 2 (EDG4); $\mathrm{LPA}_{3}$, lysophosphatidic acid receptor 3 (EDG7); $\mathrm{LPA}_{4}$, lysophosphatidic acid receptor type 4 (GPR23); $\mathrm{LPA}_{5}$, lysophosphatidic acid receptor 5 (GPR92); PLD, phospholipase D 
(MAP) kinase, an event resulting from the upstream induction of tyrosine kinase, MAP kinase or MAP kinase kinase (Siddiqui and Yang, 1995) and in such a system, LPA was without effect. Furthermore, several reports have excluded LPA contamination as a cause of the noted PA response (Fernandez et al., 1994; Knauss et al., 1990; Krabak and Hui, 1991; Kurz et al., 1993; Moritz et al., 1992; Ryder et al., 1993; Siddiqui and Yang, 1995). In addition, PA has been shown to behave as a partial agonist of $\mathrm{LPA}_{1}, \mathrm{LPA}_{2}$ and $\mathrm{LPA}_{3}$ receptors in recombinant LPA receptor-expressing cells, even though some investigators did not observe an agonistic property in LPA receptoroverexpression systems (An et al., 1998a; An et al., 1998b; Durgam et al., 2006; Fischer et al., 2001; Fitzgerald et al., 2000).

In the previous study, we found PA may act on LPA receptors in rat C6 glioma and mouse L2071 fibroblast cells (Chang et al., 2007). In the present study we used two human colon cancer cell lines (HCT116 and HT29) to test the hypothesis that PA could act as a ligand of G-protein coupled receptor (GPCR) on the plasma membrane and also to determine if such action was mediated through LPA receptors. By employing pharmacological inhibitors of signaling molecules and LPA receptors, we investigated the signaling mechanism of PA-induced increase of $\left[\mathrm{Ca}^{2+}\right]_{i}$ and the involvement of endogenous LPA receptors in human colon cancer cells.

\section{MATERIALS AND METHODS}

\section{Materials}

1, 2-Dioleoyl-sn-glycero-3-phosphate (PA), 1-oleoyl lysophosphatidic acid (LPA) and VPC32183 were purchased from Avanti Polar Lipids (Alsbaster, AL, USA). Fura 2-AM was obtained from Calbiochem (Darmstadt, Germany) while pertussis toxin (PTX), Ki16425, and other materials were purchased from Sigma-Aldrich (St. Louis, MO, USA).

\section{Cell culture}

Human HCT116 and HT29 colon cancer cells were maintained in high glucose DMEM, containing $10 \%(\mathrm{v} / \mathrm{v})$ fetal bovine serum, 100 units $/ \mathrm{mL}$ penicillin, $50 \mu \mathrm{g} / \mathrm{mL}$ streptomycin, $2 \mathrm{mM}$ glutamine, and $1 \mathrm{mM}$ sodium pyruvate, at $37^{\circ} \mathrm{C}$ in a humidified $5 \% \mathrm{CO}_{2}$ incubator.

\section{Measurement of intracellular $\mathrm{Ca}^{2+}$ concentration}

Cells were trypsin-digested, allowed to sediment, resus- pended in Hepes-buffered medium (HBM), consisting of 20 mM Hepes (pH 7.4), $103 \mathrm{mM} \mathrm{NaCl}, 4.8 \mathrm{mM} \mathrm{KCl}, 1.2 \mathrm{mM}$

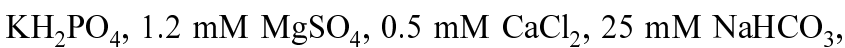
$15 \mathrm{mM}$ glucose and $0.1 \%$ bovine serum albumin (fatty acid free), and then incubated for 40 min with $5 \mu \mathrm{M}$ fura 2-AM for subsequent $\mathrm{Ca}^{2+}$ measurement. The amount of $\left[\mathrm{Ca}^{2+}\right]_{\mathrm{i}}$ was estimated from a change in the fluorescence of the fura 2-loaded cells (Yun et al., 2004). Fluorescence emission at $510 \mathrm{~nm}$ wavelength from two excitation wavelengths (340 nm and 380 $\mathrm{nm}$ ) were measured every $0.1 \mathrm{sec}$ by F4500 fluorescence spectrophotometer (Hitachi, Japan), and the ratio of fluorescence intensities from the two wavelengths was monitored as an estimate of $\left[\mathrm{Ca}^{2+}\right]_{\mathrm{i}}$ (Chang et al., 2006).

\section{Reverse Transcriptase-PCR}

To identify expression of LPA receptors in HCT116 and HT29 cells by RT-PCR, first strand cDNA was synthesized with total RNA isolated by using the Promega ImProm-II Reverse Transcription System (Madison, WI, USA). Synthesized cDNA products along with primers for $\mathrm{LPA}_{1-5}$ were used for PCR by using Promega Go-Taq DNA polymerase (Madison, WI, USA). Specific primers for $\mathrm{LPA}_{1}$ (sense 5'- CAG GAC CCA ATA CTC GGA GA -3', antisense 5'- GTT GAA AAT GGC CCA GAA GA -3'), LPA $_{2}$ (sense 5'- TTT CAC TTG AGG GCT GGT TC -3', antisense 5'- CAT GAG CAG GAA GAC AAG CA -3'), $\mathrm{LPA}_{3}$ (sense 5'- CTC ATG GCC TTC CTC ATC AT-3', antisense 5'- GCC ATA CAT GTC CTC GTC CT -3'), $\mathrm{LPA}_{4}$ (sense 5'- CTT CGC AAG CCT GCT ACT CT -3', antisense 5'- GGC TTT GTG GTC AAA GGT GT -3') and $\mathrm{LPA}_{5}$ (sense 5'- TCT CCC GTG TCC TGA CTA CC -3', antisense 5'- TGA GCA TCA GGA AGA TGC AG $3^{\prime}$ ') were used to amplify $317,317,321,341$ and 308 bps of fragments of $\mathrm{LPA}_{1-5}$, respectively. The PCR reaction was performed by 30 cycles of denaturation at $95^{\circ} \mathrm{C}$ for $1 \mathrm{~min}$, annealing at $55^{\circ} \mathrm{C}$ for $1 \mathrm{~min}$, and elongation at $72^{\circ} \mathrm{C}$ for $2 \mathrm{~min}$ in an Eppendorf Mastcycler gradient PCR machine (Hamburg, Germany) (Yun et al., 2004). Ten $\mu l$ of aliquots were electrophoresed in $1.2 \%$ agarose gels and stained with ethidium bromide.

\section{Statistics}

The results are expressed as means \pm SE for the number of indicated determinations. Statistical significance of the differences was determined by ANOVA with significance accepted when $\mathrm{P}<0.05$. 
A

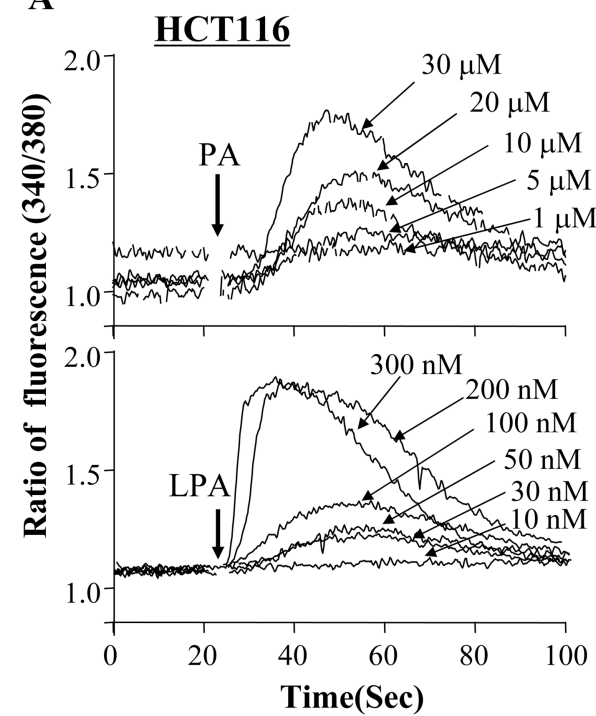

B

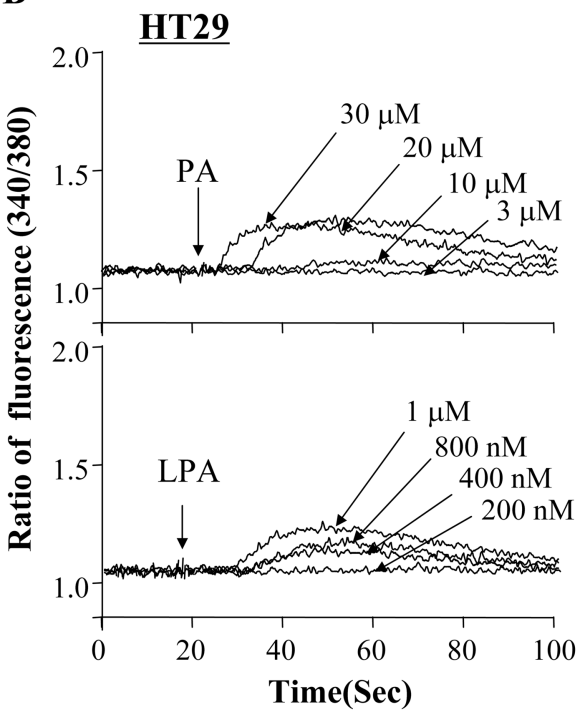

Fig. 1. Concentration-dependence of LPA- and PA-induced $\mathrm{Ca}^{2+}$ increases in HCT116 and HT29 human colon cancer cells. Representative $\mathrm{Ca}^{2+}$ traces with different concentrations of PA (upper panel) and LPA (lower panel) in HCT116 cells (A) or in HT29 human colon cancer cells (B). Each arrow indicates when the lipid was added. The data shown are representative of three independent experiments.

\section{RESULTS}

\section{PA and LPA increase intracellular $\mathrm{Ca}^{2+}$ concentration in HCT116 and HT29 human colon cancer cells.}

PA and LPA increased intracellular $\mathrm{Ca}^{2+}$ concentrations in both cell lines and in a concentration-dependent manner (Fig.

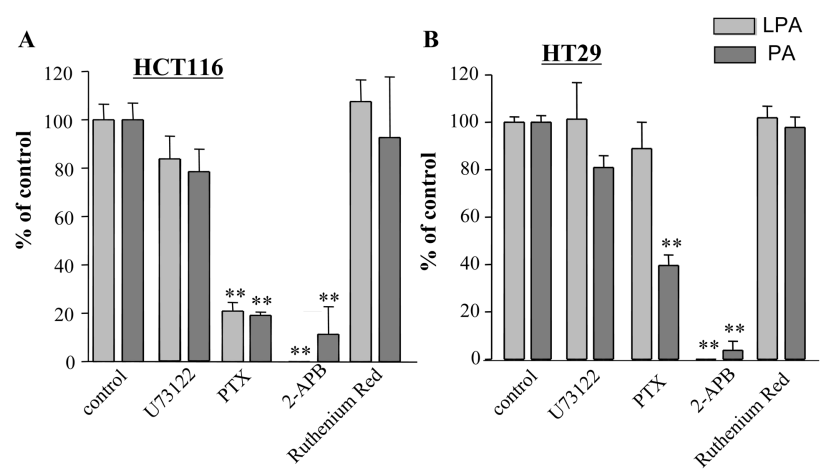

Fig. 2. Effects of U73122, PTX, 2-APB, ruthenium red on PAand LPA-induced $\mathrm{Ca}^{2+}$ increases. Cells treated with U73122 (5 $\mu \mathrm{M}, 10 \mathrm{~min})$, PTX (100 ng/mL, $24 \mathrm{hr}), 2-\mathrm{APB}(100 \mu \mathrm{M}, 10$ $\mathrm{min})$, ruthenium red $(20 \mu \mathrm{M}, 10 \mathrm{~min})$ or with nothing were used for $\mathrm{Ca}^{2+}$ measurements with $100 \mathrm{nM}$ of LPA or $5 \mu \mathrm{M}$ of PA in HCT116 (A) or $800 \mathrm{nM}$ of LPA or $30 \mu \mathrm{M}$ of PA in HT29 cells $(B)$. Data are presented as means \pm SE of three independent experiments (A and $\mathrm{B}$ ). Statistical significance: $* * P<0.01$ vs. non-treated cells.
1). HCT116 cells showed a greater response to PA and LPA than did HT29 cells (Fig. 1). As shown Fig. 1, LPA was more potent than PA by increasing intracellular $\mathrm{Ca}^{2+}$ concentrations in both cell types.

\section{Effects of U73122, PTX, 2-APB, and ruthenium red on PA- and LPA-induced $\mathrm{Ca}^{2+}$ responses.}

To characterize the intracellular $\mathrm{Ca}^{2+}$ responses to both lipids, we treated cells with specific inhibitors (U73122, PTX, 2$\mathrm{APB}$, ruthenium red) of phospholipase $\mathrm{C}, \mathrm{G}_{\mathrm{i} / \mathrm{o}}$-type $\mathrm{G}$ proteins, inositol 1,4,5-trisphosphate $\left(\mathrm{IP}_{3}\right)$ receptor, and ryanodine receptor, respectively. As shown in Fig. 2, U73122 and ruthenium red were not inhibitory on the responses of PA and LPA in the two cell types. However, PTX, a specific inhibitor of $\mathrm{G}_{\mathrm{i} / \mathrm{o}}$ type $G$ proteins was inhibitory on the responses except for an LPAinduced effect in the HT29 cells. In addition, 2-APB, a specific inhibitor of the $\mathrm{IP}_{3}$ receptor, was seen to completely inhibit both lipid-induced $\mathrm{Ca}^{2+}$ increases in the two cell types. These results suggest that both LPA and PA mobilize $\mathrm{Ca}^{2+}$ through PTX-sensitive $\mathrm{G}$ proteins and $\mathrm{IP}_{3}$ receptors in the HCT116 cells. On the other hand, PA mobilizes $\mathrm{Ca}^{2+}$ through moderately PTX-sensitive G proteins (about 60\%) and $\mathrm{IP}_{3}$ receptors in HT29 cells. However, LPA mobilizes $\mathrm{Ca}^{2+}$ through PTXinsensitive $\mathrm{G}$ proteins and $\mathrm{IP}_{3}$ receptors in the $\mathrm{HT} 29$ cells. 

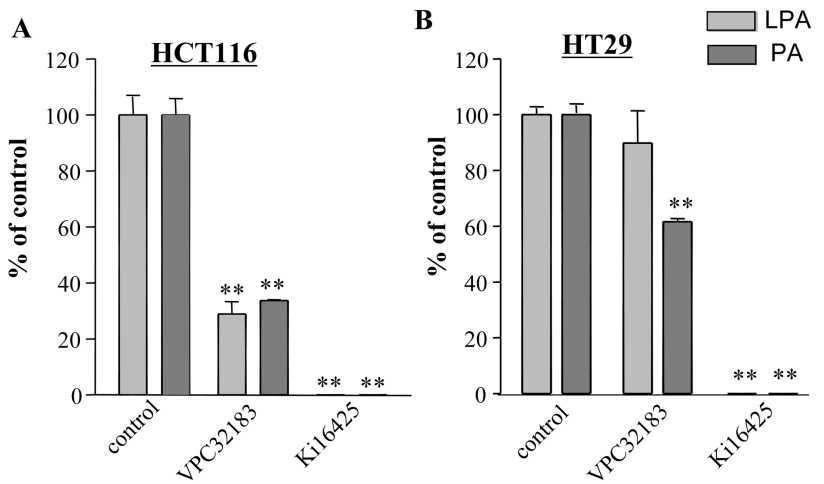

Fig. 3. Effects of Ki16425 and VPC 32183 on PA- and LPAinduced $\mathrm{Ca}^{2+}$ increases. Cells treated with VPC32183 $(20 \mu \mathrm{M})$, Ki16425 $(100 \mu \mathrm{M})$ or without were used for $\mathrm{Ca}^{2+}$ measurements with $100 \mathrm{nM}$ of LPA or $5 \mu \mathrm{M}$ of PA in HCT116 (A) or $800 \mathrm{nM}$ of LPA or $30 \mu \mathrm{M}$ of PA in HT29 (B). Data are presented as means $\pm \mathrm{SE}$ of three independent experiments (A and B). Statistical significance: $* * P<0.01$ vs. non-treated cells.

\section{Effects of Ki16425 and VPC32183 on PA- and LPA- induced $\mathrm{Ca}^{2+}$ responses}

We tested the effects of Ki16425 and VPC32183, two structurally-different antagonists of $\mathrm{LPA}_{1} / \mathrm{LPA}_{3}$ receptors to determine a possible involvement of endogenously expressed LPA receptors in the $\mathrm{Ca}^{2+}$ responses. As shown in Fig. 3, Ki16425 completely inhibited both LPA- and PA-induced $\mathrm{Ca}^{2+}$ responses in both HCT116 and HT29 cells. On the other hand, VPC32183, a structurally-different specific inhibitor of LPA $_{1}$ / $\mathrm{LPA}_{3}$ receptors, inhibited LPA- and PA-induced $\mathrm{Ca}^{2+}$ responses by nearly $70 \%$ in HCT116 cells (Fig. 3) and for PA-induced $\mathrm{Ca}^{2+}$ increase of $40 \%$ but not at all for an LPA-induced one in HT29 cells (Fig. 3). Therefore, PA and LPA appear to increase $\left[\mathrm{Ca}^{2+}\right]_{\mathrm{i}}$ through Ki16425/VPC32183-sensitive LPA receptors coupled to PTX-sensitive G proteins mainly in HCT116 cells. In the HT29 cells, however, LPA increases $\left[\mathrm{Ca}^{2+}\right]_{\mathrm{i}}$ through a Ki16425-sensitive and VPC32183-insensitive LPA receptor population coupled to PTX-insensitive G proteins, whereas PA utilized Ki16425-sensitive and partially VPC32183-sensitive LPA receptors where those LPA receptors are coupled to PTXsensitive and insensitive $G$ proteins.

\section{Expression of LPA receptors in HCT116 and HT29 cells}

RT-PCR was conducted to analyze expression levels of five LPA receptors, including the recently-identified LPA receptors, $\mathrm{LPA}_{4}$ (GPR23) and LPA (GPR92) (Kotarsky et al., 2006; Lee et al., 2006; Lee et al., 2007; Noguchi et al., 2003; Yanagida et al., 2007). $\mathrm{LPA}_{1}$ and $\mathrm{LPA}_{4}$ were strongly expressed in human

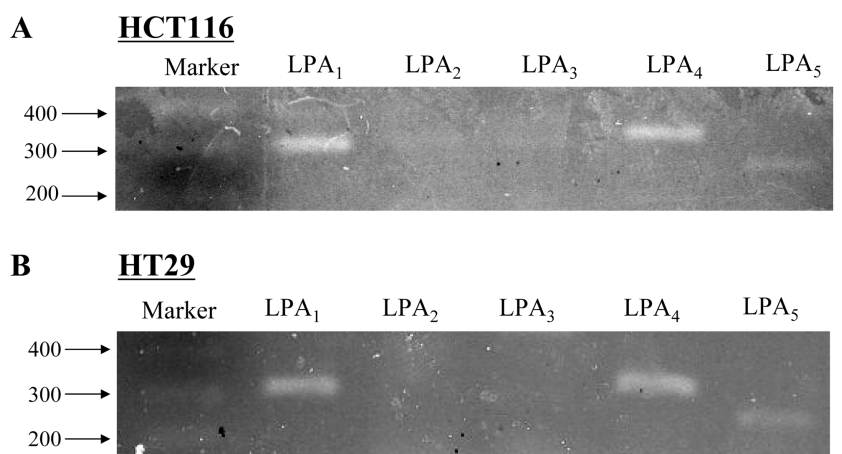

Fig. 4. Expression analysis of five LPA receptors in the HCT116 and HT29 human colon cancer cells. RT-PCR was performed using mRNAs extracted from HCT116 and HT29 cells. The data is representative of three independent experiments which have yielded similar results.

colon cancer cells and $\mathrm{LPA}_{5}$ was moderately detected; $\mathrm{LPA}_{2}$ and $\mathrm{LPA}_{3}$ were barely detected in either cell line (Fig. 4).

\section{DISCUSSION}

Although much research has focused on the second messenger roles of PA as a signaling product of phospholipase D (PLD) (Fang et al., 2001; Hornberger et al., 2006; Stace and Ktistakis, 2006), a first messenger role of PA on GPCR needs to be considered as well (English et al., 1996), since there are several metabolic enzymes for PA (e.g. glycosylphosphatidylinositol-specific PLD in serum (Huang et al., 1991) and ectophosphatidic acid phosphohydrolase (English et al., 1997) and PA-specific phospholipase $\mathrm{A}_{2}$ (Hiramatsu et al., 2003; Sonoda et al., 2002) in the plasma membrane which suggests production and degradation of PA in the extracellular milieu.

In recombinant LPA receptor-expressing cells, PA has been shown to be a partial agonist for $\mathrm{LPA}_{1}, \mathrm{LPA}_{2}$ and $\mathrm{LPA}_{3}$ receptors (An et al., 1998a; An et al., 1998b; Fitzgerald et al., 2000). However, partial agonism of PA in LPA receptor-overexpression systems remains largely controversial (Durgam et al., 2006; Fischer et al., 2001). Previously, we found an action of PA on endogenous LPA receptors in rat C6 glioma and mouse L2071 fibroblasts (Chang et al., 2007). Thus, we have questioned whether PA could act as a ligand of GPCR on the plasma membrane and also whether the action is mediated through endogenous LPA receptors in human colon cancer cell lines. By employing pharmacological inhibitors of signaling molecules and LPA receptors, we have determined that PA increased $\left[\mathrm{Ca}^{2+}\right]_{\mathrm{i}}$ through endogenously expressed LPA receptors in the 
cancer cell lines. We also observed differential susceptibility of PA- and LPA-induced responses in the HCT116 and HT29 cells to treatment with PTX, 2-APB, Ki16425, and VPC32183. PTX-sensitivity, VPC32183-sensitivity, and complete inhibitory effects by 2-APB and Ki16425 were observed in HCT116 cells, however, differential sensitivity to PTX and VPC32183 and complete inhibition by 2-APB and Ki16425 were observed in HT29 cells. It seems likely that mainly PTX- and VPC 32183-insensitive LPA receptor type mediates $\mathrm{Ca}^{2+}$ increase by LPA in HT29 cells. However, PTX- and VPC32183-sensitive LPA receptor type is somewhat involved in the PA-induced $\mathrm{Ca}^{2+}$ increase. On the other hand, in HCT116 cells PTX-, Ki16425-, and the VPC32183-sensitive LPA receptor type primarily mediates the LPA- and PA-induced $\mathrm{Ca}^{2+}$ responses with but a small portion of the response mediated via PTX- and VPC32183-insensitve LPA receptors. The expression levels of LPA receptors in the two cancer cell lines show no significant differences. Thus, the disparity of antagonist susceptibilities of PA- and LPA-induced $\mathrm{Ca}^{2+}$ responses from the two cell lines can not be explained by expression of subtype LPA receptors. Differential coupling of LPA receptors and G proteins, however, could be the explanation (Im et al., 2005; Kajiyama and Ui, 1994). Unfortunately, existing information on the susceptibility of the recently-identified LPA receptors $\left(\mathrm{LPA}_{4}\right.$ and $\left.\mathrm{LPA}_{5}\right)$ to both antagonists has not been made available, thereby limiting a more complete assessment of our results (Kotarsky et al., 2006; Lee et al., 2006; Lee et al., 2007; Noguchi et al., 2003; Yanagida et al., 2007).

Although further investigation is necessary to confirm production of PA in the extracellular milieu and antagonist susceptibilities of the $\mathrm{LPA}_{4}$ and $\mathrm{LPA}_{5}$, our present results regarding a first messenger role of PA and its agonistic effects on endogenous LPA receptors in human colon cancer cells would strongly suggest it to be an intercellular bioactive lipid mediator in human being.

\section{ACKNOWLEDGMENTS}

This work was supported by the Korea Science and Engineering Foundation (KOSEF) grant funded by the government of Korea (MOST) (R01-2005-000-10011-02005).

\section{REFERENCES}

An, S., Bleu, T., Hallmark, O. G. and Goetzl, E. J. (1998a). Characterization of a novel subtype of human $G$ protein-coupled receptor for lysophosphatidic acid. J. Biol. Chem. 273, 79067910.

An, S., Bleu, T., Zheng, Y. and Goetzl, E. J. (1998b). Recombinant human $\mathrm{G}$ protein-coupled lysophosphatidic acid receptors mediate intracellular calcium mobilization. Mol. Pharmacol. 54, 881-888.

Barritt, G. J., Dalton, K. A. and Whiting, J. A. (1981). Evidence that phosphatidic acid stimulates the uptake of calcium by liver cells but not calcium release from mitochondria. FEBS Lett. 125, 137-140.

Bashir, N., Kuhen, K. and Taub, M. (1992). Phospholipids regulate growth and function of MDCK cells in hormonally defined serum free medium. In Vitro Cell Dev. Biol. 28A, 663-668.

Chang, Y. J., Lee, Y. K., Lee, E. H., Park, J. J., Chung, S. K. and Im, D. S. (2006). Structure-activity relationships of dimethylsphingosine (DMS) derivatives and their effects on intracellular $\mathrm{pH}$ and $\mathrm{Ca}^{2+}$ in the U937 monocyte cell line. Arch. Pharm. Res. 29, 657-665.

Chang, Y. J., Kim, Y. L., Lee, Y. K., Sacket, S. J., Kim, K., Kim, H. L., Han, M., Bae, Y. S., Okajima, F. and Im, D. S. (2007). Dioleoyl phosphatidic acid increases intracellular $\mathrm{Ca}^{2+}$ through endogenous LPA receptors in C6 glioma and L2071 fibroblasts. Prostaglandins Other Lipid Mediat. 83, 268-276.

Durgam, G. G., Tsukahara, R., Makarova, N., Walker, M. D., Fujiwara, Y., Pigg, K. R., Baker, D. L., Sardar, V. M., Parrill, A. L., Tigyi, G. and Miller, D. D. (2006). Synthesis and pharmacological evaluation of second-generation phosphatidic acid derivatives as lysophosphatidic acid receptor ligands. Bioorg. Med. Chem. Lett. 16, 633-640.

English, D., Cui, Y. and Siddiqui, R. A. (1996). Messenger functions of phosphatidic acid. Chem. Phys. Lipids. 80, 117-132.

English, D., Martin, M., Harvey, K. A., Akard, L. P., Allen, R., Widlanski, T. S., Garcia, J. G. and Siddiqui, R. A. (1997). Characterization and purification of neutrophil ecto-phosphatidic acid phosphohydrolase. Biochem. J. 324 ( Pt 3), 941-950.

Fang, Y., Vilella-Bach, M., Bachmann, R., Flanigan, A. and Chen, J. (2001). Phosphatidic acid-mediated mitogenic activation of mTOR signaling. Science. 294, 1942-1945.

Fernandez, B., Balboa, M. A., Solis-Herruzo, J. A. and Balsinde, J. (1994). Phosphatidate-induced arachidonic acid mobilization in mouse peritoneal macrophages. J. Biol. Chem. 269, 26711-26716.

Fischer, D. J., Nusser, N., Virag, T., Yokoyama, K., Wang, D., Baker, D. L., Bautista, D., Parrill, A. L. and Tigyi, G. (2001). Short-chain phosphatidates are subtype-selective antagonists of lysophosphatidic acid receptors. Mol. Pharmacol. 60, 776-784.

Fitzgerald, L. R., Dytko, G. M., Sarau, H. M., Mannan, I. J., Ellis, C., Lane, P. A., Tan, K. B., Murdock, P. R., Wilson, S., Bergsma, D. J., Ames, R. S., Foley, J. J., Campbell, D. A., McMillan, L., Evans, N., Elshourbagy, N. A., Minehart, H. and Tsui, P. (2000). Identification of an EDG7 variant, HOFNH30, a Gprotein-coupled receptor for lysophosphatidic acid. Biochem. Biophys. Res. Commun. 273, 805-810.

Gerrard, J. M., Butler, A. M., Peterson, D. A. and White, J. G. (1978). Phosphatidic acid releases calcium from a platelet membrane fraction in vitro. Prostaglandins Med. 1, 387-396.

Harris, R. A., Schmidt, J., Hitzemann, B. A. and Hitzemann, R. J. (1981). Phosphatidate as a molecular link between depolarization and neurotransmitter release in the brain. Science $\mathbf{2 1 2}$, 1290-1291.

Hiramatsu, T., Sonoda, H., Takanezawa, Y., Morikawa, R., Ishida, M., Kasahara, K., Sanai, Y., Taguchi, R., Aoki, J. and Arai, H. (2003). Biochemical and molecular characterization of two phos- 
phatidic acid-selective phospholipase $\mathrm{A}_{1} \mathrm{~s}, \mathrm{mPA}-\mathrm{PLA}_{1 \alpha}$ and mPAPLA $_{1 \beta}$. J. Biol. Chem. 278, 49438-49447.

Hornberger, T. A., Chu, W. K., Mak, Y. W., Hsiung, J. W., Huang, S. A. and Chien, S. (2006). The role of phospholipase D and phosphatidic acid in the mechanical activation of mTOR signaling in skeletal muscle. Proc. Natl. Acad. Sci. U. S. A. 103, 4741-4746.

Huang, K. S., Li, S. and Low, M. G. (1991). Glycosylphosphatidylinositol-specific phospholipase D. Methods Enzymol. 197, 567-575.

Ikeda, Y., Kikuchi, M., Toyama, K., Watanabe, K. and Ando, Y. (1979). Ionophoretic activities of phospholipids on human platelets. Thromb. Haemost. 41, 779-786.

Im, D. S., Nagano, K., Katada, T., Okajima, F. and Ui, M. (2005). Differential change of Ins- $\mathrm{P}_{3}-\mathrm{Ca}^{2+}$ signaling during culture of rat hepatocytes. Cell Signal .17, 83-91.

Imai, A., Ishizuka, Y., Kawai, K. and Nozawa, Y. (1982). Evidence for coupling of phosphatidic acid formation and calcium influx in thrombin-activated human platelets. Biochem. Biophys. Res. Commun. 108, 752-759.

Jalink, K., van Corven, E. J. and Moolenaar, W. H. (1990). Lysophosphatidic acid, but not phosphatidic acid, is a potent $\mathrm{Ca}^{2+}$ mobilizing stimulus for fibroblasts. Evidence for an extracellular site of action. J. Biol. Chem. 265, 12232-12239.

Kajiyama, Y. and Ui, M. (1994). Switching from alpha 1- to betasubtypes in adrenergic response during primary culture of adult-rat hepatocytes as affected by the cell-to-cell interaction through plasma membranes. Biochem. J. 303 ( Pt 1), 313-321.

Kawase, T. and Suzuki, A. (1988). Phosphatidic acid-induced calcium mobilization in osteoblasts. J. Biochem. (Tokyo) 103, 581-582.

Kawase, T. and Suzuki, A. (1990). Initial responses of a clonal osteoblast-like cell line, MOB 3-4, to phosphatidic acid in vitro. Bone Miner. 10, 61-70.

Knauss, T. C., Jaffer, F. E. and Abboud, H. E. (1990). Phosphatidic acid modulates DNA synthesis, phospholipase $\mathrm{C}$, and platelet-derived growth factor mRNAs in cultured mesangial cells. Role of protein kinase C. J. Biol. Chem. 265, 14457-14463.

Kotarsky, K., Boketoft, A., Bristulf, J., Nilsson, N. E., Norberg, A., Hansson, S., Sillard, R., Owman, C., Leeb-Lundberg, F. L. and Olde, B. (2006). Lysophosphatidic Acid Binds to and Activates Gpr92, a G Protein-Coupled Receptor Highly Expressed in Gastro-Intestinal Lymphocytes. J. Pharmacol. Exp. Ther. 318, 619-628.

Krabak, M. J. and Hui, S. W. (1991). The mitogenic activities of phosphatidate are acyl-chain-length dependent and calcium independent in $\mathrm{C} 3 \mathrm{H} / 10 \mathrm{~T} 1 / 2$ cells. Cell Regul. 2, 57-64.

Kurz, T., Wolf, R. A. and Corr, P. B. (1993). Phosphatidic acid stimulates inositol 1,4,5-trisphosphate production in adult cardiac myocytes. Circ. Res. 72, 701-706.

Lee, C. H., Reisine, T. D. and Wax, M. B. (1989). Alterations of intracellular calcium in human non-pigmented ciliary epithelial cells of the eye. Exp. Eye Res. 48, 733-743.

Lee, C. W., Rivera, R., Gardell, S., Dubin, A. E. and Chun, J. (2006). GPR92 as a New $\mathrm{G}_{12 / 13^{-}}$and $\mathrm{G}_{\mathrm{q}}$-coupled Lysophosphatidic Acid Receptor That Increases cAMP, $\mathrm{LPA}_{5}$. J. Biol. Chem. 281, 23589-23597.
Lee, C. W., Rivera, R., Dubin, A. E. and Chun, J. (2007). LPA 4 GPR23 is an LPA receptor utilizing $\mathrm{G}_{\mathrm{s}}, \mathrm{G}_{\mathrm{q}} / \mathrm{G}_{\mathrm{i}}$-mediated calcium signaling and $\mathrm{G}_{12 / 13}$-mediated Rho activation. J. Biol. Chem. 282, 4310-4317.

McGhee, J. G. and Shoback, D. M. (1990). Effects of phosphatidic acid on parathyroid hormone release, intracellular free $\mathrm{Ca}^{2+}$, and inositol phosphates in dispersed bovine parathyroid cells. Endocrinology 126, 899-907.

Moritz, A., De Graan, P. N., Gispen, W. H. and Wirtz, K. W. (1992). Phosphatidic acid is a specific activator of phosphatidylinositol-4-phosphate kinase. J. Biol. Chem. 267, 7207-7210.

Noguchi, K., Ishii, S. and Shimizu, T. (2003). Identification of p2y9/GPR23 as a novel G protein-coupled receptor for Lysophosphatidic acid, structurally distant from the Edg family. $J$. Biol. Chem. 278, 25600-25606.

Osugi, T., Uchida, S., Watanabe, Y. and Yoshida, H. (1984). Differences in $\mathrm{Ca}^{2+}$ mobilization induced by alpha-adrenergic agonist and phosphatidic acid in cultured hepatocytes. Life Sci. $\mathbf{3 5}$, 469-475.

Pearce, B., Jakobson, K., Morrow, C. and Murphy, S. (1994). Phosphatidic acid promotes phosphoinositide metabolism and DNA synthesis in cultured cortical astrocytes. Neurochem. Int. 24, 165-171.

Ryder, N. S., Talwar, H. S., Reynolds, N. J., Voorhees, J. J. and Fisher, G J. (1993). Phosphatidic acid and phospholipase D both stimulate phosphoinositide turnover in cultured human keratinocytes. Cell Signal. 5, 787-794.

Siddiqui, R. A. and Yang, Y. C. (1995). Interleukin-11 induces phosphatidic acid formation and activates MAP kinase in mouse 3T3-L1 cells. Cell Signal. 7, 247-259.

Siegmann, D. W. (1987). Stimulation of quiescent 3T3 cells by phosphatidic acid-containing liposomes. Biochem. Biophys. Res. Commun. 145, 228-233.

Sonoda, H., Aoki, J., Hiramatsu, T., Ishida, M., Bandoh, K., Nagai, Y., Taguchi, R., Inoue, K. and Arai, H. (2002). A novel phosphatidic acid-selective phospholipase $\mathrm{A}_{1}$ that produces lysophosphatidic acid. J. Biol. Chem. 277, 34254-34263.

Stace, C. L. and Ktistakis, N. T. (2006). Phosphatidic acid- and phosphatidylserine-binding proteins. Biochim. Biophys. Acta. 1761, 913-926.

van Corven, E. J., Groenink, A., Jalink, K., Eichholtz, T. and Moolenaar, W. H. (1989). Lysophosphatidate-induced cell proliferation: identification and dissection of signaling pathways mediated by $\mathrm{G}$ proteins. Cell 59, 45-54.

Weiss, S. J., McKinney, J. S. and Putney, J. W., Jr. (1982). Regulation of phosphatidate synthesis by secretagogues in parotid acinar cells. Biochem. J. 204, 587-592.

Wood, C. A., Padmore, L. and Radda, G. K. (1993). The effect of phosphatidic acid on the proliferation of Swiss $3 \mathrm{~T} 3$ cells. Biochem. Soc. Trans. 21, 369S.

Yanagida, K., Ishii, S., Hamano, F., Noguchi, K. and Shimizu, T. (2007). $\mathrm{LPA}_{4} / \mathrm{p} 2 \mathrm{y}$ /GPR23 mediates Rho-dependent morphological changes in a rat neuronal cell line. J. Biol. Chem. 282, 5814-5824.

Yun, M. R., Okajima, F. and Im, D. S. (2004). The action mode of lysophosphatidylcholine in human monocytes. J. Pharmacol. Sci. 94, 45-50. 